\title{
Notes on the vocalizations of Ornate Antwren (Myrmotherula ornata)
}

Peter Boesman

In the following we briefly analyze and compare voice of the different races of Ornate Antwren (Myrmotherula ornata). We also try to quantify the extent of any vocal differences using the criteria proposed by Tobias et al. (2010), as a support for taxonomic review.

We have made use of sound recordings available on-line from Xeno Canto (XC).

Song of Ornate Antwren is a short high-pitched trill initiated with one or more longer notes. Some trills however lack these introductory notes, and it is not clear if these are 'short songs' or a vocalization with a different function.

We have only measured what appeared to be 'full songs' with at least one longer introductory note (Table 1).

\begin{tabular}{|l|l|l|l|}
\hline & $\begin{array}{l}\text { hoffmannsi } \\
(n=5)\end{array}$ & $\begin{array}{l}\text { meridionalis/ } \\
\text { atrogularis( } n=5)\end{array}$ & $\begin{array}{l}\text { ornata/ } \\
\text { saturata(n=4) }\end{array}$ \\
\hline \# notes 1st note & $9-21$ & $13-24$ & $11-13$ \\
\hline length $0.08-0.1 \mathrm{~s}$ & $0.07-0.1 \mathrm{~s}$ & $0.08-0.1 \mathrm{~s}$ \\
\hline max. freq. in trill & $6100-7700 \mathrm{~Hz}$ & $6400-7500 \mathrm{~Hz}$ & $6300-7000 \mathrm{~Hz}$ \\
\hline $\begin{array}{l}\text { max. freq. lowest } \\
\text { note }\end{array}$ & $4100-5400 \mathrm{~Hz}$ & $5000-5900 \mathrm{~Hz}$ & $5400-5800 \mathrm{~Hz}$ \\
\hline $\begin{array}{l}\text { fastest pace over 5 } \\
\text { notes (s) }\end{array}$ & $0.074-0.09$ & $0.07-0.091$ & $0.1-0.137$ \\
\hline total length & $0.86-1.6 \mathrm{~s}$ & $1.06-2.35 \mathrm{~s}$ & $1.34-2.03 \mathrm{~s}$ \\
\hline $\begin{array}{l}\text { frequency drop in } \\
\text { trill }\end{array}$ & $1500-3300 \mathrm{~Hz}$ & $1200-1600 \mathrm{~Hz}$ & $800-1600 \mathrm{~Hz}$ \\
\hline $\begin{array}{l}\text { number of long } \\
\text { intro notes }\end{array}$ & $\begin{array}{l}1 \text { (with typically } \\
\text { frequency spike } \\
\text { at start) }\end{array}$ & $\begin{array}{l}1 \text { (with usually } \\
\text { round overslurred } \\
\text { shape) }\end{array}$ & $\begin{array}{l}2 \text { with stuttering } \\
\text { start }\end{array}$ \\
\hline
\end{tabular}

Table 1: measurement of basic sound parameters for races of Ornate Antwren (Myrmotherula ornata)

From Table 1 we can deduct that there are slight differences in voice of typical loudsongs (Figure 1):

hoffmannsi has the largest frequency drop towards the end of the trill (score 1 or 2 ) and has a single long introductory note with usually spiky shape (score 1)

ornata/saturata has typically a stuttering start to the trill with two long introductory notes (score 2) and a slower pace in the trill (score 1 or 2 ). 

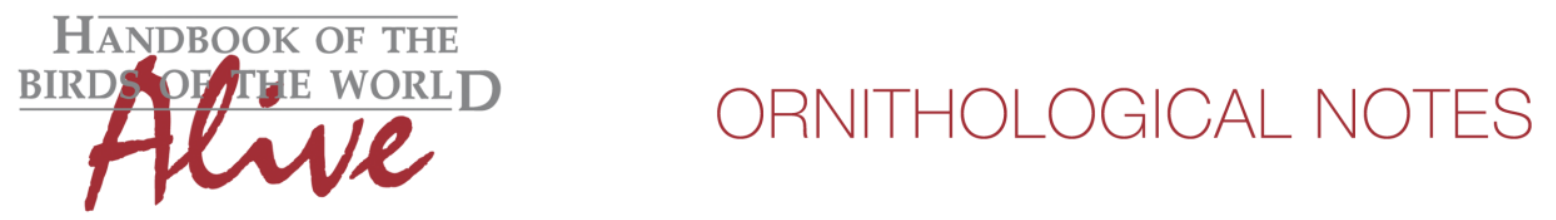

meridionalis/atrogularis has the single introductory note (although more rounded overslurred) from hoffmannsi but much less frequency drop, more like ornata/saturata.

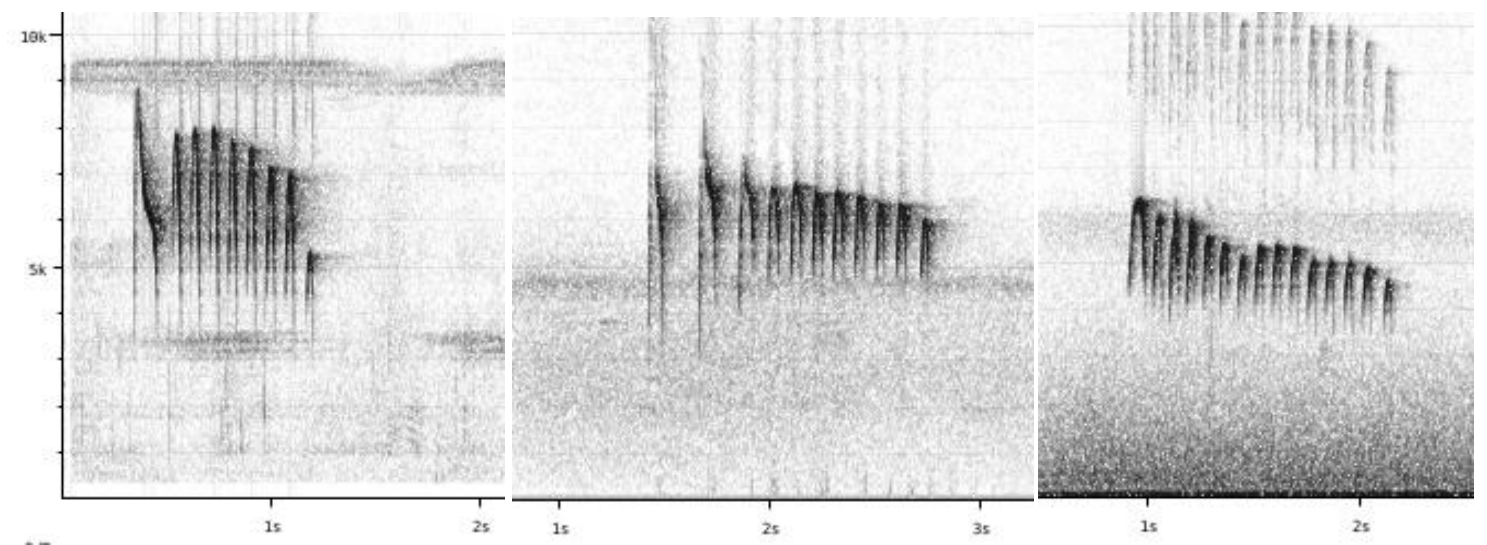

Figure 1: example of song for respectively hoffmannsi, ornata/saturata and meridionalis/atrogularis

All in all, it would seem that the typical loudsongs of the three groups are fairly distinctive, with a score of about 2-3 each vs. both other groups.

This note was finalized on 4th May 2015, using sound recordings available on-line at that moment. We would like to thank in particular the sound recordists who placed their recordings for this species on XC: Roger Ahlman, Nick Athanas, Peter Boesman, Guilherme Brito, Taylor Brooks, Eric DeFonso, David Geale, Niels Krabbe, Frank Lambert, Dan Lane, Gabriel Leite, Mitch Lysinger, Hans Matheve, Jeremy Minns, John V. Moore, Jonas Nilsson, Eduardo Patrial, Fabrice Schmitt, Andrew Spencer, Joseph Tobias and Nathalie Seddon, and Charlie Vogt.

\section{References}

Tobias, J.A., Seddon, N., Spottiswoode, C.N., Pilgrim, J.D., Fishpool, L.D.C. \& Collar, N.J. (2010). Quantitative criteria for species delimitation. Ibis 152(4): 724-746.

\section{Recommended citation}

Boesman, P. (2016). Notes on the vocalizations of Ornate Antwren (Myrmotherula ornata). HBW Alive Ornithological Note 45. In: Handbook of the Birds of the World Alive. Lynx Edicions, Barcelona. (retrieved from http://www.hbw.com/node/931753 on 25 April 2016). 